\title{
Maximizing Land Use Efficiency by Intercropping Cowpea with Some Maize Cultivars under Different Maize Planting Geometries
}

\author{
Yasser E. El-Ghobashy, Amr S. Shams, Mohamed M. Lamlom \\ Crop Intensification Research Department, Field Crops Research Institute, Agricultural Research Center, Giza, Egypt \\ Email: dr_amrshams@yahoo.com
}

How to cite this paper: El-Ghobashy, Y.E., Shams, A.S. and Lamlom, M.M. (2018) Maximizing Land Use Efficiency by Intercropping Cowpea with Some Maize Cultivars under Different Maize Planting Geometries. Agricultural Sciences, 9, 1601-1620. https://doi.org/10.4236/as.2018.912112

Received: November 26, 2018 Accepted: December 17, 2018 Published: December 20, 2018

Copyright ( 92018 by authors and Scientific Research Publishing Inc. This work is licensed under the Creative Commons Attribution International License (CC BY 4.0).

http://creativecommons.org/licenses/by/4.0/

\begin{abstract}
Adjustment of planting geometry along with suitable maize cultivar can be a viable tool for maximizing land usage and net return. A two-year study was carried out at Serw Agricultural Experiments and Research Station, A.R.C., Domiate governorate, Egypt, during 2015 and 2016 seasons to evaluate intercropping cowpea with suitable maize cultivar and its planting geometry for maximizing land usage and net return. The treatments were the combinations between three maize cultivars (SC 30K08, TWC 310 and TWC 352) and three maize plant distributions (one plant/hill distanced at 25, 50 and $75 \mathrm{~cm}$ between hills, respectively). Ridge width with maize plant distribution formed maize planting geometry $(25 \mathrm{~cm} \times 140 \mathrm{~cm}, 50 \mathrm{~cm} \times 140 \mathrm{~cm}$ and $75 \mathrm{~cm} \times 140$ $\mathrm{cm})$. These treatments were compared in a split plot distribution in randomized complete block design with three replications. Maize cultivar SC 30K08 had the highest grain yield and its attributes compared with the other cultivars in both seasons. Also, maize planting geometry $25 \mathrm{~cm} \times 140 \mathrm{~cm}$ resulted in the highest grain yield and its attributes compared with the other planting geometries in both seasons. Ear length, ear weight, 100-grain weight and grain yield/fad were affected significantly by maize cultivars $\times$ maize planting geometry. Intercropping cowpea with maize cultivar TWC 352 had the highest seed yield and its attributes compared with those intercropped with the other cultivars in both seasons. Also, maize planting geometry $75 \mathrm{~cm} \times 140$ $\mathrm{cm}$ resulted in the highest seed yield and its attributes through growing two cowpea rows between maize hills compared with the other maize planting geometries in both seasons. Number of pods/plant and seed yield/fad were affected significantly by maize cultivars $\times$ maize planting geometry. LER and LEC values of the intercrops were much greater than 1.00 and 0.25 , respectively, for all the combinations indicating less land requirements of intercropping system than solid culture of both crops. Growing one row of maize
\end{abstract}


cultivar TWC352 in both sides of bed $140 \mathrm{~cm}$ width with cowpea two rows in middle of the bed increased land productivity and net return compared with solid culture of maize.

\section{Keywords}

Intercropping, Maize Cultivars, Maize Planting Geometry, Cowpea, Competitive Relationships, Farmers' Benefit

\section{Introduction}

It is known that maize (Zea mays L.) is a strategic crop and it is used for human consumption, animal and poultry feeding, as well as, industrial purposes. It is the world's most widely grown cereal and produced cereal crops [1]. The total cultivated area of maize has reached about 1.7 million fads [2]. Consequently, it is expected that maize cultivar and its plant distribution could play a vital role with any cropping system to increase land usage. However, the cropping system adopted by the farmer in Egypt must be physically viable, sustainable, less exhaustive acceptable to farming community and most important thing is that it should be economical.

The biggest complementary effects and biggest yield advantages occur when the component crops have different growing periods, so make their major demands on resources at different times [3]. Certainly, legumes are noteworthy in that most of them have symbiotic N-fixing bacteria in structures called root nodules [4]. So, legumes are a useful means to sustain organic matter content and thereby enhance the biological activity, improve soil fertility and increase nutrient availability [5] and [6]. Cowpea (Vigna unguiculata [L.] Walp) is an important grain legume throughout the tropics and subtropics covering Africa, Asia, central and south America, its value lies in its high protein content and it fixes atmospheric nitrogen with high efficiency which allows it to grow on and improve poor soils [7]. Consequently, intercropping systems that include legumes can provide symbiotically fixed $\mathrm{N}$ and potentially increase yield through improved resource use efficiency [8].

Egyptian breeders produced many single and three-way hybrids such as single crosses (SC) 128, SC Ageeb, SC 101, SC 124 and SC161, as well as, three-way hybrids (TWC) 310 and TWC352. Such hybrids differed in their assimilating capacity and distribution of photosynthates between the various plant organs, which could be referred to source and sink relation [9]. Naturally, there were significant genetic differences for morphological parameter among maize genotypes [10]. Accordingly, selection of cultivars with more erect leaves, especially at the top of the canopy, has led to improved light environments inside a canopy and hence improved canopy photosynthetic $\mathrm{CO}_{2}$ uptake rate [11]. In another study, Storck et al. [12] showed that there is variability among hybrids which 
does not follow a tendency of genetic variability between single, three-way and double hybrids. Although S.C. 122 cultivar had more yield potential than TWC 310 or Giza 2 cultivar but it is not suitable for intercropping culture [13]. Consequently, maize cultivar that interacts positively with an intercropping pattern could play an important role to reach advantages of intercropping plantings.

Certainly, optimum plant spacing ensures plants to grow properly both in their above and underground parts through different utilization of solar radiation and nutrient. It is known that commercial crop as maize is typically grown at a smaller distance between hills $(25 \mathrm{~cm})$ within the same row than distance between these rows. However, plant spacing varies with the growth of plants and the growing environments [14]. On the other hand, crop geometry refers to the shape of the space available for individual plants and it is altered by changing planting pattern [15]. Accordingly, spacing is a practice that determines the spatial distribution of plants and affects canopy structure, light interception, and radiation use efficiency and, consequently, biomass or grain yield [16]. Although doubling maize number unit area ${ }^{-1}$ by increasing spacing between plants from 30 to $60 \mathrm{~cm}$ led to the similarity in plant density unit area ${ }^{-1}$, there were significant increments in maize yield and its attributes under intercropping and sole culture [17]. Therefore, the objective of this investigation was to evaluate intercropping cowpea with suitable maize cultivar and its planting geometry for maximizing land usage and net return.

\section{Materials and Methods}

A two-year study was carried out at El-Serw Agricultural Experiments and Research Station, A.R.C., Domiate Governorate (Lat. 31 $24^{\prime} 59^{\prime \prime N}$, Long. $31^{\circ} 48^{\prime} 47^{\prime \prime E}$, $16 \mathrm{~m}$ a.s.l.), Egypt during 2015 and 2016 seasons to evaluate intercropping cowpea with suitable maize cultivar and its planting geometry for maximizing land usage and net return. Wheat was the preceding winter crop in both seasons. Furrow irrigation was the irrigation system in the area. Cowpea cultivar Cream 7 and maize cultivars; SC 30K08, TWC 310 and TWC 352 were used in the study. The treatments were the combination between three maize cultivars and three maize plant distributions (Figure 1) as follows:

- Growing two plants of maize cultivar SC 30K08, TWC 310 or TWC 352 per hill distanced at $25 \mathrm{~cm}$ between hills which distributed to one row in both sides of bed $140 \mathrm{~cm}$ width (one row/side), meanwhile, $150 \mathrm{~g}$ of cowpea seeds were drilled in two rows in middle of the bed (two cowpea rows between maize rows) in the same direction of maize rows. After three weeks from planting, plants of maize and cowpea were thinned to one plant/hill distanced at 25 and $10 \mathrm{~cm}$ between hills, respectively, this system was expressed as $25 \mathrm{~cm} \times 140 \mathrm{~cm}$.

- Growing two plants of maize cultivar SC 30K08, TWC 310 or TWC 352 per hill distanced at $50 \mathrm{~cm}$ between hills which distributed to four rows in bed $140 \mathrm{~cm}$ width, meanwhile, $150 \mathrm{~g}$ of cowpea seeds were drilled into five rows 


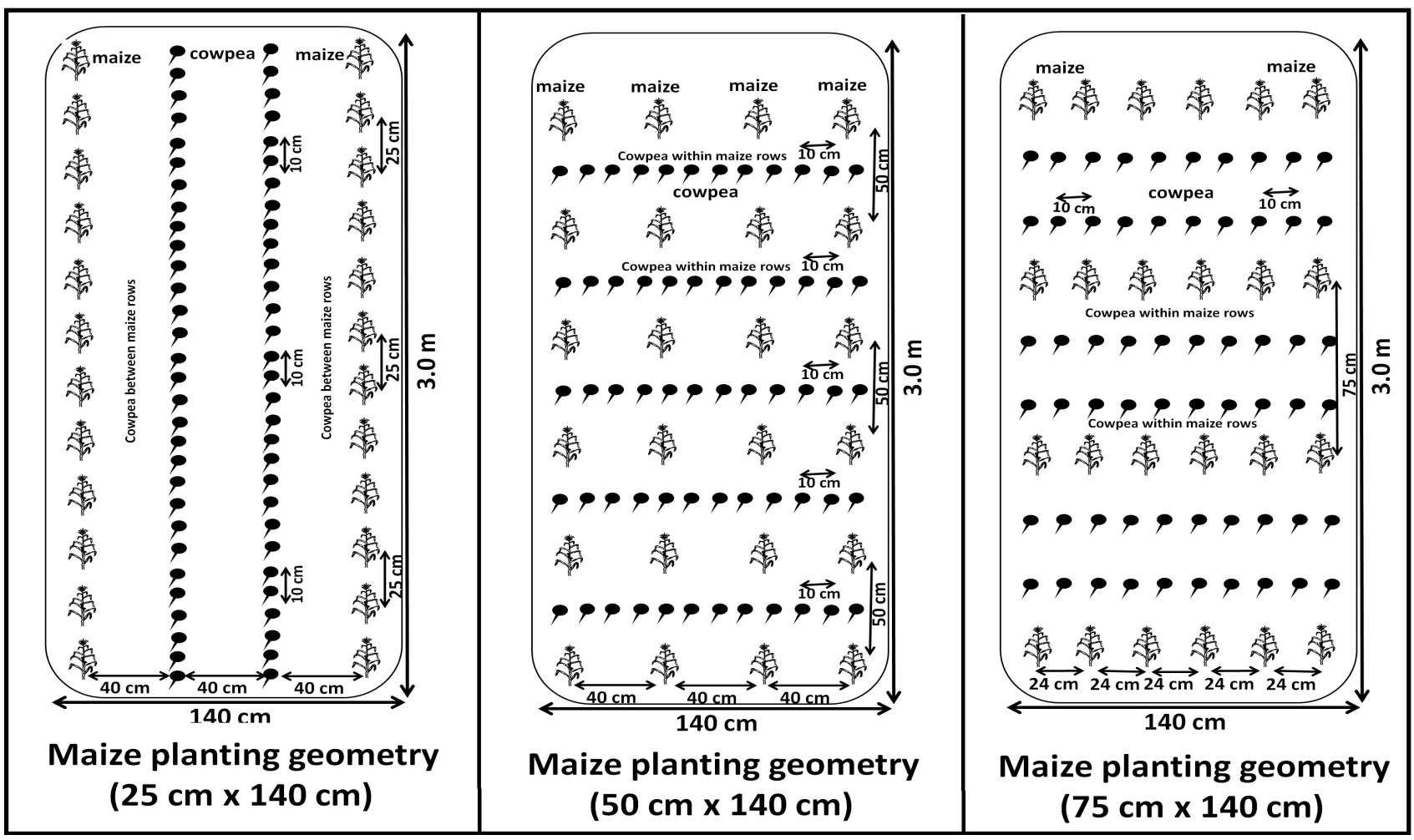

Figure 1. Intercropping cowpea with maize under different maize planting geometries.

within the four maize rows (one cowpea row between maize hills) in a perpendicular direction on the direction of maize rows. After three weeks from planting, plants of maize and cowpea were thinned to one plant/hill distanced at 50 and $10 \mathrm{~cm}$ between hills, respectively. This system was expressed as $50 \mathrm{~cm} \times 140 \mathrm{~cm}$.

- Growing two plants of maize cultivar SC30K08, TWC 310 or TWC 352 per hill distanced at $75 \mathrm{~cm}$ between hills which distributed to six rows in bed 140 $\mathrm{cm}$ width, meanwhile, $150 \mathrm{~g}$ of cowpea seeds were drilled into six rows within the six maize rows (two cowpea rows between maize hills) in a perpendicular direction on the direction of the maize rows. After three weeks from planting, plants of maize and cowpea were thinned to one plant/hill distanced at 75 and $10 \mathrm{~cm}$ between hills, respectively. This system was expressed as $75 \mathrm{~cm}$ $\times 140 \mathrm{~cm}$.

In addition:

- Solid culture of maize cultivar SC30K08, TWC 310 or TWC 352 by growing two plants per hill distanced at $25 \mathrm{~cm}$ between hills which distributed to one row in one side of ridge $70 \mathrm{~cm}$ width. After three weeks from planting, the seedlings of maize were thinned to one plant/hill distanced at $25 \mathrm{~cm}$ between hills.

- Solid culture of cowpea by drilling one row of cowpea in both sides of ridge $70 \mathrm{~cm}$ width (one row/side). After three weeks from planting, the seedlings of cowpea were thinned to one plant/hill distanced at $10 \mathrm{~cm}$ between hills. 
Solid cultures of crops were used to estimate the competitive relationships. Maize grains and cowpea seeds were sown on May $27^{\text {th }}$ and $31^{\text {st }}$ in 2015 and 2016 seasons, respectively. Calcium super phosphate $\left(15.5 \% \mathrm{P}_{2} \mathrm{O}_{5}\right)$ at rate of 150 $\mathrm{kg} / \mathrm{fad}$ was applied during soil preparation in the two summer seasons. Ridge width with maize plant distribution formed maize planting geometry $(25 \mathrm{~cm} \times$ $140 \mathrm{~cm}, 50 \mathrm{~cm} \times 140 \mathrm{~cm}$ and $75 \mathrm{~cm} \times 140 \mathrm{~cm}$ ). Cowpea seeds were inoculated by Rhizobium melitota before seeding it and Arabic gum was used as a sticking agent. Mineral N fertilizer of maize was applied at rate of $120 \mathrm{~kg} \mathrm{~N} / \mathrm{fad}$ at 15 and 30 days from maize planting under intercropping and solid cultures. Mineral $\mathrm{N}$ fertilizer of cowpea was applied at rate of 7.5 and $15 \mathrm{~kg} \mathrm{~N} / \mathrm{fad}$ at 15 days from cowpea planting under intercropping and solid cultures, respectively. Cowpea plants were thinned to one plant per hill distanced at $10 \mathrm{~cm}$ between hills under intercropping and solid cultures. In all treatments, the population of maize was uniformly maintained at 24,000 plants per fad. On the other hand, the population of cowpea was uniformly maintained at 60,000 and 120,000 plants per fad in intercropping and solid cultures, respectively. These treatments were compared in a split plot distribution in randomized complete block design with three replications. Maize cultivars were randomly assigned to the main plots and maize plant distributions were allocated in sub-plots. The area of plot was $25.2 \mathrm{~m}^{2}$, it consisted of 6 beds, and each ridge was $3.0 \mathrm{~m}$ in length and $1.4 \mathrm{~m}$ in width.

\subsection{The Studied Traits}

\section{1) Maize grain yield and its attributes}

At harvest, the following traits were measured on ten plants from each sub plot: plant height $(\mathrm{cm})$, number of green leaves/plant, ear length $(\mathrm{cm})$, ear weight $(\mathrm{g})$, number of rows/ear and 100-grain weight $(\mathrm{g})$. Grain yield of maize/fad (ardab) was recorded on the basis of experimental plot area by harvesting all plants of each sub plot (one fad $=1 / 2.38 \mathrm{ha}$, one $\operatorname{ardab}=140 \mathrm{~kg}$ ).

\section{2) Cowpea seed yield and its attributes}

At harvest, the following traits were measured on ten plants from each sub plot: plant height $(\mathrm{cm})$, number of branches/plant, leaf area/plant, number of pods/plant, number of seeds/plant and 100-seed weight $(\mathrm{g})$. Seed yield/fad $(\mathrm{kg})$ was recorded on the basis of experimental plot area by harvesting all plants of each sub plot (one fad $=1 / 2.38$ ha).

\section{3) Competitive relationships}

Land equivalent ratio (LER): LER defines as the ratio of area needed under sole cropping to one of intercropping at the same management level to produce an equivalent yield [18]. It is calculated as follows: LER $=\left(\mathrm{Y}_{\mathrm{ab}} / \mathrm{Y}_{\mathrm{aa}}\right)+\left(\mathrm{Y}_{\mathrm{ba}} / \mathrm{Y}_{\mathrm{bb}}\right)$, where $Y_{a a}=$ Pure stand yield of crop a (maize), $Y_{b b}=$ Pure stand yield of crop $b$ (cowpea), $\mathrm{Y}_{\mathrm{ab}}=$ Intercrop yield of crop a (maize) and $\mathrm{Y}_{\mathrm{ba}}=$ Intercrop yield of crop b (cowpea).

Land Equivalent Coefficient (LEC): LEC is a measure of interaction concerned with the strength of relationship [19]. It is calculated as follows: $\mathrm{LEC}=\mathrm{L}_{a}$ 
$\times L_{b}$, where: $L_{a}=$ relative yield of crop a (maize) and $L_{b}=$ relative yield of crop $b$ (cowpea).

\section{4) Economic evaluation}

Farmer's benefit was calculated by determining the total costs and net return of intercropping culture as compared to recommended solid culture of maize.

- Total return of intercropping cultures $=$ Price of maize yield + price of cowpea yield (L.E.).

- Net return/fad $=$ Total return $-($ fixed costs of maize + variable costs of cowpea according to intercropping pattern).

The average of maize price presented by Bulletin of Statistical Cost Production and Net Return [2] and the average of cowpea prices presented by maker price were used. The local prices were L.E. 343 of one ardab of maize grains and L.E. 25 of one $\mathrm{kg}$ of cowpea seeds.

\subsection{The Statistical Analysis}

Analysis of variance of the obtained results of each season was performed. The measured variables were analyzed by ANOVA using MSTATC statistical package [20]. Mean comparisons were performed using the least significant differences (L.S.D) test with a significance level of 5\% [21].

\section{Results and Discussion}

\subsection{Maize Grain Yield and Its Attributes}

\subsubsection{Maize Cultivars}

Maize cultivars were differed significantly for plant height, ear length, ear weight, number of rows/ear, 100-grain weight and grain yield/fad, meanwhile number of green leaves/plant was not differed among maize cultivars in both seasons (Table 1 and Table 2). With regard to plant height, maize cultivar SC $30 \mathrm{~K} 08$ gave higher plant height than TWC 310 or TWC 352 by 7.52 or $23.60 \%$ in the first season and by $10.82 \%$ or $25.14 \%$ in the second one, respectively, under intercropping conditions. These results probably due to there was more shading around canopy of maize plants of maize cultivar SC 30K08 which formed more amounts of plant hormones and resulted in an increase of the internode number and elongation compared with the other cultivars. Mutual shading is known to increase the proportion of invisible radiation, which has a specific elongating effect upon plants [22]. Certainly, maize plant needs to receive and absorb optimal solar radiation to strength the stems.

With respect to grain yield and its attributes, maize cultivar SC $30 \mathrm{~K} 08$ had the highest ear length, ear weight, number of rows/ear, 100-grain weight and grain yield/fad compared with the other cultivars in both seasons (Table 1 and Table 2). These results probably due to genetic potential of maize cultivar SC 30K08 translated into suitable canopy architecture that induced a deeper root system and a faster horizontal root development, indicting efficient use of all nutrients by all parts of this cultivar compared with the others cultivars. Hence, genetic 
variability among the three hybrids led to differences in ear characteristics as a result of assimilates and it's partitioning to the cob. It seems that maize cultivar SC 30K08 was more effective in translocating photosynthates from leaves and stalks to the developing ears than TWC 310 or TWC 352 under intercropping conditions. According to Abo-Shetaia et al. [9], the difference in the genetical constituent of different maize cultivars might account much to difference in length and size of ears, especially there was a positive and highly correlated relationship among ear fill, ear length and ear circumference with grain weight/ear [23]. So, it is likely that differences in canopy and root architectures among the maize cultivars played a major role in utilization from the basic growth resources which reflected on ear characteristics under intercropping conditions. Leaf area is usually influenced by genotype, planting density, climate and soil fertility [24]. On the other hand, Lamlom et al. [13] showed that maize cultivar SC 122 had high capacity of root system that can make a larger volume of soil available for root extraction of water and nutrients compared to the other cultivars.

\subsubsection{Maize Planting Geometry}

Ear length, ear weight, 100-grain weight and grain yield/fad were affected significantly by maize planting geometry, meanwhile plant height, number of green leaves/plant and number of rows/ear were not affected in both seasons (Table 1 and Table 2). Maize planting geometry $25 \mathrm{~cm} \times 140 \mathrm{~cm}$ resulted in the highest ear length, ear weight and 100-grain weight and grain yield/fad compared with other planting geometries in both seasons. Decreasing distance between maize hills from 75 to $25 \mathrm{~cm}$ increased ear length, ear weight, 100-grain weight and grain yield/fad by $7.78 \%, 15.92 \%, 11.26 \%$ and $27.67 \%$, respectively in the first season.

Also, ear length, ear weight, 100-grain weight and grain yield/fad were increased by $21.76 \%, 19.84 \%, 24.67 \%$ and $21.92 \%$, respectively, by decreasing distance between maize hills from 75 to $25 \mathrm{~cm}$ in the second one. These results may be due to differences in maize planting geometry led to differences in ear characteristics through intra-specific competition between maize plants for climatic and edaphic environmental conditions. It is likely that spatial arrangement of maize plants was differed by growing maize plant at different distances between hills although similarity in plant density per unit area which reflected on grain germination, the timely appearance of seedling and the development of shoot and root systems. Accordingly, it is expected that the adverse effects of shading between maize rows was higher than those between maize hills and these effects were reduced by decreasing distances between maize hills from 75 to $25 \mathrm{~cm}$. Extreme uneven plant distribution reduced grain yield [25] and [26]. These results reveal that canopy architecture of maize plant that distanced at $25 \mathrm{~cm}$ between hills benefited greatly from available environmental resources especially solar energy which reflected positively on more translocation of photosynthates 
metabolites to the sink (ears). In maize crop canopy, leaf area and vertical leaf area profile influence the interception and utilization of solar radiation which consequently drive dry matter accumulation and results the grain yield [27].

\subsubsection{Interaction between Maize Cultivars and Maize Planting Geometry} Ear length, ear weight, 100-grain weight and grain yield/fad were affected significantly by maize cultivars $\times$ maize planting geometry, meanwhile plant height, number of green leaves/plant and number of rows/ear were not affected in both seasons (Table 1 and Table 2). The highest values of ear length, ear weight, 100-grain weight and grain yield/fad were obtained by intercropping cowpea with maize cultivar SC $30 \mathrm{~K} 08$ of planting geometry $25 \mathrm{~cm} \times 140 \mathrm{~cm}$ compared with the others. These results may be due to maize cultivar SC 30K08 of planting geometry $25 \mathrm{~cm} \times 140 \mathrm{~cm}$ led to largely balance in maize-to-maize competition for climatic and edaphic environmental conditions compared with the other

Table 1. Effect of maize cultivars, maize planting geometry and their interaction on grain yield of maize and its attributes in the first season.

\begin{tabular}{|c|c|c|c|c|c|c|c|c|}
\hline $\begin{array}{l}\text { Maize } \\
\text { cultivars }\end{array}$ & $\begin{array}{l}\text { Maize planting } \\
\text { geometry }\end{array}$ & $\begin{array}{l}\text { Plant height } \\
(\mathrm{cm})\end{array}$ & $\begin{array}{c}\text { Number of green } \\
\text { leaves/plant }\end{array}$ & $\begin{array}{l}\text { Ear length } \\
\quad(\mathrm{cm})\end{array}$ & $\begin{array}{c}\text { Ear weight } \\
(\mathrm{g})\end{array}$ & $\begin{array}{l}\text { Number of } \\
\text { rows/ear }\end{array}$ & $\begin{array}{l}\text { 100-grain } \\
\text { weight }(\mathrm{g})\end{array}$ & $\begin{array}{c}\text { Grain yield/fad } \\
\text { (ardab) }\end{array}$ \\
\hline \multirow{4}{*}{ SC $30 \mathrm{~K} 08$} & $25 \mathrm{~cm} \times 140 \mathrm{~cm}$ & 292.00 & 14.08 & 23.16 & 284.33 & 18.05 & 32.51 & 26.20 \\
\hline & $50 \mathrm{~cm} \times 140 \mathrm{~cm}$ & 289.00 & 14.39 & 23.01 & 276.66 & 16.20 & 31.94 & 24.49 \\
\hline & $75 \mathrm{~cm} \times 140 \mathrm{~cm}$ & 300.33 & 14.55 & 21.80 & 261.00 & 14.28 & 30.82 & 21.36 \\
\hline & Mean & 293.77 & 14.34 & 22.66 & 273.96 & 16.17 & 31.76 & 24.01 \\
\hline \multirow{4}{*}{ TWC 310} & $25 \mathrm{~cm} \times 140 \mathrm{~cm}$ & 285.66 & 14.41 & 18.00 & 221.00 & 15.00 & 28.31 & 20.91 \\
\hline & $50 \mathrm{~cm} \times 140 \mathrm{~cm}$ & 273.33 & 14.58 & 17.91 & 187.00 & 14.93 & 27.53 & 17.56 \\
\hline & $75 \mathrm{~cm} \times 140 \mathrm{~cm}$ & 260.66 & 14.91 & 16.10 & 164.66 & 14.31 & 24.66 & 15.55 \\
\hline & Mean & 273.22 & 14.63 & 17.33 & 190.88 & 14.75 & 26.83 & 18.01 \\
\hline \multirow{4}{*}{ TWC 352} & $25 \mathrm{~cm} \times 140 \mathrm{~cm}$ & 228.66 & 14.33 & 17.43 & 217.66 & 16.41 & 30.45 & 20.59 \\
\hline & $50 \mathrm{~cm} \times 140 \mathrm{~cm}$ & 238.00 & 14.40 & 16.90 & 213.33 & 14.02 & 28.73 & 17.72 \\
\hline & $75 \mathrm{~cm} \times 140 \mathrm{~cm}$ & 246.33 & 14.56 & 16.48 & 198.00 & 13.29 & 26.55 & 16.10 \\
\hline & Mean & 237.66 & 14.43 & 16.93 & 209.66 & 14.57 & 28.57 & 18.14 \\
\hline \multirow{3}{*}{$\begin{array}{l}\text { Average of } \\
\text { maize planting } \\
\text { geometry }\end{array}$} & $25 \mathrm{~cm} \times 140 \mathrm{~cm}$ & 268.77 & 14.27 & 19.53 & 240.99 & 16.48 & 30.42 & 22.56 \\
\hline & $50 \mathrm{~cm} \times 140 \mathrm{~cm}$ & 266.77 & 14.45 & 19.27 & 225.66 & 15.05 & 29.40 & 19.92 \\
\hline & $75 \mathrm{~cm} \times 140 \mathrm{~cm}$ & 269.11 & 14.68 & 18.12 & 207.88 & 13.96 & 27.34 & 17.67 \\
\hline \multicolumn{2}{|c|}{ L.S.D. at 0.05 Maize cultivars } & 6.68 & N.S. & 1.01 & 21.92 & 0.87 & 2.65 & 3.62 \\
\hline \multicolumn{2}{|c|}{ L.S.D. at 0.05 Maize planting geometry } & N.S. & N.S. & 0.74 & 10.49 & N.S. & 1.93 & 2.80 \\
\hline \multicolumn{2}{|c|}{ L.S.D. at 0.05 Interaction } & N.S. & N.S. & 1.53 & 33.17 & N.S. & 3.08 & 5.32 \\
\hline \multirow{3}{*}{$\begin{array}{l}\text { Solid culture } \\
\text { of maize }\end{array}$} & SC 30K08 & 265.00 & 16.00 & 22.00 & 280.00 & 17.09 & 31.30 & 26.95 \\
\hline & TWC 310 & 300.00 & 16.00 & 18.15 & 221.00 & 15.15 & 28.20 & 21.49 \\
\hline & TWC 352 & 350.00 & 15.00 & 18.10 & 225.00 & 14.85 & 30.40 & 21.68 \\
\hline
\end{tabular}

One fad $=4200 \mathrm{~m}^{2}$. One $\mathrm{ardab}=140 \mathrm{~kg}$ of maize grains. 
Table 2. Effect of maize cultivars, maize planting geometry and their interaction on grain yield of maize and its attributes in the second season.

\begin{tabular}{|c|c|c|c|c|c|c|c|c|}
\hline $\begin{array}{c}\text { Maize } \\
\text { cultivars }\end{array}$ & $\begin{array}{l}\text { maize planting } \\
\text { geometry }\end{array}$ & $\begin{array}{l}\text { Plant } \\
\text { height } \\
(\mathrm{cm})\end{array}$ & $\begin{array}{c}\text { Number of } \\
\text { green leaves } \\
\text { /plant }\end{array}$ & $\begin{array}{l}\text { Ear length } \\
\quad(\mathrm{cm})\end{array}$ & $\begin{array}{c}\text { Ear weight } \\
\text { (g) }\end{array}$ & $\begin{array}{c}\text { Number of } \\
\text { rows/ear }\end{array}$ & $\begin{array}{l}100 \text {-grain } \\
\text { weight }(\mathrm{g})\end{array}$ & $\begin{array}{l}\text { Grain yield/fad } \\
\text { (ardab) }\end{array}$ \\
\hline \multirow{4}{*}{ SC 30K08 } & $25 \mathrm{~cm} \times 140 \mathrm{~cm}$ & 314.00 & 15.66 & 25.18 & 286.66 & 20.00 & 34.53 & 27.10 \\
\hline & $50 \mathrm{~cm} \times 140 \mathrm{~cm}$ & 314.33 & 16.00 & 25.03 & 277.66 & 17.33 & 33.95 & 25.42 \\
\hline & $75 \mathrm{~cm} \times 140 \mathrm{~cm}$ & 320.66 & 16.33 & 23.81 & 262.00 & 15.33 & 32.84 & 22.26 \\
\hline & Mean & 316.33 & 16.00 & 24.67 & 275.44 & 17.55 & 33.77 & 24.92 \\
\hline \multirow{4}{*}{ TWC 310} & $25 \mathrm{~cm} \times 140 \mathrm{~cm}$ & 296.66 & 16.00 & 20.01 & 231.66 & 16.66 & 30.33 & 21.84 \\
\hline & $50 \mathrm{~cm} \times 140 \mathrm{~cm}$ & 287.00 & 16.33 & 15.12 & 199.00 & 16.00 & 29.55 & 19.46 \\
\hline & $75 \mathrm{~cm} \times 140 \mathrm{~cm}$ & 272.66 & 16.66 & 14.78 & 183.33 & 15.33 & 26.68 & 17.47 \\
\hline & Mean & 285.44 & 16.33 & 16.64 & 204.66 & 16.00 & 28.85 & 19.59 \\
\hline \multirow{4}{*}{ TWC 352} & $25 \mathrm{~cm} \times 140 \mathrm{~cm}$ & 243.66 & 16.00 & 19.44 & 228.33 & 18.00 & 32.46 & 21.49 \\
\hline & $50 \mathrm{~cm} \times 140 \mathrm{~cm}$ & 253.66 & 16.00 & 16.70 & 223.33 & 15.33 & 30.74 & 19.96 \\
\hline & $75 \mathrm{~cm} \times 140 \mathrm{~cm}$ & 261.00 & 16.33 & 14.50 & 177.66 & 14.66 & 28.56 & 18.02 \\
\hline & Mean & 252.77 & 16.11 & 16.88 & 209.77 & 16.00 & 30.59 & 19.82 \\
\hline \multirow{3}{*}{$\begin{array}{c}\text { Average of } \\
\text { maize planting } \\
\text { geometry }\end{array}$} & $25 \mathrm{~cm} \times 140 \mathrm{~cm}$ & 284.77 & 15.88 & 21.54 & 248.88 & 18.22 & 32.44 & 23.47 \\
\hline & $50 \mathrm{~cm} \times 140 \mathrm{~cm}$ & 285.00 & 16.11 & 18.95 & 233.33 & 16.22 & 31.41 & 21.61 \\
\hline & $75 \mathrm{~cm} \times 140 \mathrm{~cm}$ & 284.77 & 16.44 & 17.69 & 207.66 & 15.10 & 26.02 & 19.25 \\
\hline \multicolumn{2}{|c|}{ L.S.D. at 0.05 Maize cultivars } & 17.24 & N.S. & 1.43 & 18.65 & 1.34 & 2.44 & 3.37 \\
\hline \multicolumn{2}{|c|}{ L.S.D. at 0.05 Maize planting geometry } & N.S. & N.S. & 1.01 & 12.97 & N.S. & 1.84 & 2.96 \\
\hline \multicolumn{2}{|c|}{ L.S.D. at 0.05 Interaction } & N.S. & N.S. & 1.75 & 29.16 & N.S. & 2.77 & 5.59 \\
\hline \multirow{3}{*}{$\begin{array}{l}\text { Solid culture } \\
\text { of maize }\end{array}$} & SC $30 \mathrm{~K} 08$ & 286.00 & 18.00 & 25.50 & 280.00 & 21.00 & 34.22 & 27.61 \\
\hline & TWC 310 & 312.00 & 18.00 & 20.16 & 228.00 & 17.10 & 31.31 & 22.32 \\
\hline & TWC 352 & 365.00 & 17.00 & 20.01 & 231.50 & 17.60 & 32.41 & 22.83 \\
\hline
\end{tabular}

One $\mathrm{fad}=4200 \mathrm{~m}^{2}$. One ardab $=140 \mathrm{~kg}$ of maize grains.

treatments. These data show that each of these two factors act dependently on ear length, ear weight, 100-grain weight and grain yield/fad except plant height, number of green leaves/plant and number of rows/ear.

\subsection{Cowpea Seed Yield and Its Attributes}

\subsubsection{Maize Cultivars}

Plant height, number of branches/plant, leaf area/plant, numbers of pods and seeds/plant, 100-seed weight and seed yield/fad were affected significantly by maize cultivars in both seasons (Table 3 and Table 4).

With regard to plant height, intercropping cowpea with maize cultivar TWC 352 gave lower plant height than those intercropped with maize cultivar SC $30 \mathrm{~K} 08$ or TWC 310 in both seasons. These results probably due to differences in canopy architecture of the studied maize cultivars in the intercrops resulted in a 
shading percentage around cowpea plants with varying light proportions that required stimulating flower production. Obviously, intercropping cowpea with maize cultivar TWC 352 decreased plant height of cowpea by $24.37 \%$ and $12.92 \%$ in the first season and by $24.65 \%$ and $13.37 \%$ in the second one, than those intercropped with maize cultivar SC $30 \mathrm{~K} 08$ and TWC 310, respectively. These results are in the same context with those obtained by Idoko et al. [28] who indicated that shading effect of maize reduced the amount of solar radiation reaching the cowpea crop.

With respect to seed yield and its attributes of cowpea, intercropping cowpea with maize cultivar TWC 352 had the highest number of branches/plant, leaf area/plant, numbers of pods and seeds/plant, 100-seed weight and seed yield/fad compared with those intercropped with the other cultivars in both seasons (Table 3 and Table 4). Intercropping cowpea with maize cultivar TWC 352 increased seed yield/fad of cowpea by $28.83 \%$ and $16.18 \%$ in the first season and by $28.18 \%$ and $7.98 \%$ in the second one, than those intercropped with maize cultivar SC 30K08 and TWC 310, respectively. These results could be attributed to

Table 3. Effect of maize cultivars, maize planting geometry and their interaction on seed yield of cowpea and its attributes in the first season.

\begin{tabular}{|c|c|c|c|c|c|c|c|c|}
\hline Maize cultivars & $\begin{array}{l}\text { maize planting } \\
\text { geometry }\end{array}$ & $\begin{array}{l}\text { Plant height } \\
\text { (cm) }\end{array}$ & $\begin{array}{l}\text { Branches } \\
\text { /plant (no.) }\end{array}$ & $\begin{array}{c}\text { Leaf area/plant } \\
\left(\mathrm{cm}^{2}\right)\end{array}$ & $\begin{array}{c}\text { Pods } \\
\text { /plant (no.) }\end{array}$ & $\begin{array}{c}\text { Seeds } \\
\text { /plant (no.) }\end{array}$ & $\begin{array}{c}\text { 100-seed } \\
\text { weight }(\mathrm{g})\end{array}$ & $\begin{array}{c}\text { Seed yield/fad } \\
(\mathrm{kg})\end{array}$ \\
\hline \multirow{4}{*}{ SC $30 \mathrm{~K} 08$} & $25 \mathrm{~cm} \times 140 \mathrm{~cm}$ & 65.00 & 3.33 & 4107.66 & 31.33 & 6.33 & 14.59 & 275.66 \\
\hline & $50 \mathrm{~cm} \times 140 \mathrm{~cm}$ & 57.66 & 3.33 & 4220.00 & 36.33 & 6.33 & 14.65 & 292.33 \\
\hline & $75 \mathrm{~cm} \times 140 \mathrm{~cm}$ & 52.33 & 3.33 & 4440.00 & 44.33 & 7.66 & 15.56 & 325.66 \\
\hline & Mean & 58.33 & 3.33 & 4255.88 & 37.33 & 6.77 & 14.93 & 297.88 \\
\hline \multirow{4}{*}{ TWC 310} & $25 \mathrm{~cm} \times 140 \mathrm{~cm}$ & 56.33 & 3.66 & 4310.00 & 36.00 & 7.33 & 16.21 & 306.33 \\
\hline & $50 \mathrm{~cm} \times 140 \mathrm{~cm}$ & 51.00 & 4.33 & 4466.66 & 41.00 & 8.66 & 16.57 & 334.33 \\
\hline & $75 \mathrm{~cm} \times 140 \mathrm{~cm}$ & 44.66 & 4.66 & 4726.66 & 49.00 & 9.33 & 17.29 & 350.33 \\
\hline & Mean & 50.66 & 4.22 & 4501.11 & 42.00 & 8.44 & 16.69 & 330.33 \\
\hline \multirow{4}{*}{ TWC 352} & $25 \mathrm{~cm} \times 140 \mathrm{~cm}$ & 48.00 & 4.33 & 4683.33 & 39.00 & 8.66 & 17.92 & 365.33 \\
\hline & $50 \mathrm{~cm} \times 140 \mathrm{~cm}$ & 43.33 & 5.33 & 5000.00 & 44.00 & 9.66 & 18.12 & 386.00 \\
\hline & $75 \mathrm{~cm} \times 140 \mathrm{~cm}$ & 41.00 & 5.66 & 5110.00 & 55.00 & 10.66 & 19.10 & 400.00 \\
\hline & Mean & 44.11 & 5.11 & 4931.11 & 46.00 & 9.66 & 18.38 & 383.77 \\
\hline \multirow{3}{*}{$\begin{array}{l}\text { Average of maize } \\
\text { planting geometry }\end{array}$} & $25 \mathrm{~cm} \times 140 \mathrm{~cm}$ & 56.44 & 3.77 & 4367.00 & 35.44 & 7.44 & 16.24 & 315.77 \\
\hline & $50 \mathrm{~cm} \times 140 \mathrm{~cm}$ & 50.66 & 4.33 & 4562.22 & 40.44 & 8.22 & 16.45 & 337.55 \\
\hline & $75 \mathrm{~cm} \times 140 \mathrm{~cm}$ & 46.00 & 4.55 & 4758.88 & 49.44 & 9.22 & 17.32 & 358.66 \\
\hline \multicolumn{2}{|c|}{ L.S.D. at 0.05 Maize cultivars } & 5.60 & 1.41 & 344.13 & 2.32 & 2.02 & 0.86 & 10.93 \\
\hline \multicolumn{2}{|c|}{ L.S.D. at 0.05 Maize planting geometry } & 2.14 & 0.45 & 104.82 & 1.10 & 0.68 & 0.49 & 7.37 \\
\hline \multicolumn{2}{|c|}{ L.S.D. at 0.05 Interaction } & N.S. & N.S. & N.S. & 2.38 & N.S. & N.S. & 18.07 \\
\hline \multicolumn{2}{|c|}{ Solid culture of cowpea } & 42.33 & 7.33 & 6145.00 & 62.00 & 13.00 & 21.60 & 832.67 \\
\hline
\end{tabular}

One fad $=4200 \mathrm{~m}^{2}$. 
Table 4. Effect of maize cultivars, maize planting geometry and their interaction on seed yield of cowpea and its attributes in the second season.

\begin{tabular}{|c|c|c|c|c|c|c|c|c|}
\hline Maize cultivars & $\begin{array}{l}\text { maize planting } \\
\text { geometry }\end{array}$ & $\begin{array}{l}\text { Plant height } \\
\quad(\mathrm{cm})\end{array}$ & $\begin{array}{l}\text { Branches } \\
\text { /plant (no.) }\end{array}$ & $\begin{array}{c}\text { Leaf area/plant } \\
\left(\mathrm{cm}^{2}\right)\end{array}$ & $\begin{array}{c}\text { Pods } \\
\text { /plant (no.) }\end{array}$ & $\begin{array}{c}\text { Seeds } \\
\text { /plant (no.) }\end{array}$ & $\begin{array}{c}\text { 100-seed } \\
\text { weight }(\mathrm{g})\end{array}$ & $\begin{array}{c}\text { Seed yield/fad } \\
(\mathrm{kg})\end{array}$ \\
\hline \multirow{4}{*}{ SC $30 \mathrm{~K} 08$} & $25 \mathrm{~cm} \times 140 \mathrm{~cm}$ & 61.66 & 3.33 & 4136.66 & 27.00 & 5.33 & 13.55 & 195.66 \\
\hline & $50 \mathrm{~cm} \times 140 \mathrm{~cm}$ & 55.33 & 3.33 & 4193.33 & 30.66 & 5.33 & 13.63 & 208.66 \\
\hline & $75 \mathrm{~cm} \times 140 \mathrm{~cm}$ & 49.33 & 3.33 & 4396.66 & 37.66 & 6.33 & 14.58 & 231.00 \\
\hline & Mean & 55.44 & 3.33 & 4242.22 & 31.77 & 5.66 & 13.92 & 211.77 \\
\hline \multirow{4}{*}{ TWC 310} & $25 \mathrm{~cm} \times 140 \mathrm{~cm}$ & 54.00 & 3.66 & 4280.00 & 32.00 & 6.33 & 15.21 & 254.33 \\
\hline & $50 \mathrm{~cm} \times 140 \mathrm{~cm}$ & 49.00 & 4.33 & 4452.66 & 37.33 & 7.66 & 15.55 & 277.66 \\
\hline & $75 \mathrm{~cm} \times 140 \mathrm{~cm}$ & 41.66 & 4.33 & 4703.33 & 40.33 & 8.33 & 16.61 & 290.66 \\
\hline & Mean & 48.22 & 4.11 & 4478.66 & 36.55 & 7.44 & 15.79 & 274.21 \\
\hline \multirow{4}{*}{ TWC 352} & $25 \mathrm{~cm} \times 140 \mathrm{~cm}$ & 45.66 & 4.66 & 4623.33 & 32.33 & 7.66 & 17.25 & 279.33 \\
\hline & $50 \mathrm{~cm} \times 140 \mathrm{~cm}$ & 40.66 & 5.33 & 4953.66 & 40.00 & 8.66 & 17.27 & 296.66 \\
\hline & $75 \mathrm{~cm} \times 140 \mathrm{~cm}$ & 39.00 & 5.33 & 5093.33 & 46.66 & 9.33 & 18.45 & 312.33 \\
\hline & Mean & 41.77 & 5.11 & 4890.11 & 39.66 & 8.55 & 17.65 & 296.10 \\
\hline \multirow{3}{*}{$\begin{array}{l}\text { Average of maize } \\
\text { planting geometry }\end{array}$} & $25 \mathrm{~cm} \times 140 \mathrm{~cm}$ & 53.77 & 3.88 & 4346.66 & 30.44 & 6.44 & 15.34 & 243.10 \\
\hline & $50 \mathrm{~cm} \times 140 \mathrm{~cm}$ & 48.33 & 4.33 & 4533.22 & 36.00 & 7.22 & 15.48 & 260.99 \\
\hline & $75 \mathrm{~cm} \times 140 \mathrm{~cm}$ & 43.33 & 4.33 & 4731.11 & 41.55 & 8.00 & 16.54 & 277.99 \\
\hline \multicolumn{2}{|c|}{ L.S.D. at 0.05 Maize cultivars } & 5.01 & 1.50 & 383.59 & 4.47 & 1.96 & 0.56 & 22.18 \\
\hline \multicolumn{2}{|c|}{ L.S.D. at 0.05 Maize planting geometry } & 2.09 & N.S. & 93.28 & 2.30 & 0.68 & 0.20 & 15.50 \\
\hline \multicolumn{2}{|c|}{ L.S.D. at 0.05 Interaction } & N.S. & N.S. & N.S. & 4.64 & N.S. & N.S. & 26.84 \\
\hline \multicolumn{2}{|c|}{ Solid culture of cowpea } & 49.66 & 7.00 & 6210.00 & 57.66 & 11.66 & 22.07 & 676.66 \\
\hline
\end{tabular}

One $\mathrm{fad}=4200 \mathrm{~m}^{2}$.

genetic variability among the three hybrids which led to difference in yield attributes of cowpea as a result of intercropping conditions. It seems that cowpea plants was more adapted with maize cultivar TWC 352 and benefited from basic growth resources than those intercropped with maize cultivar SC 30K08 or TWC 310.

It is likely that canopy and root architectures of maize cultivar TWC 352 played a major role to furnish better above and underground conditions for cowpea growth and development. These findings imply that canopy architecture of maize cultivar TWC 352 contributed largely in climatic resources availability particularly solar energy which reflected positively on more translocation of photosynthates metabolites to the pod. It is known that shading throughout, or from first flower onwards, reduced seed yield by about $25 \%$ because fewer pods were produced [29]. Also, differences in the depth of roots, lateral root spread and root densities are some of the factors that affect competition between the component crops in an intercropping system for nutrients [30]. Naturally, cowpea plant as $\mathrm{C}_{3}$ plant of photosynthetic pathways had lower ability to use available 
growth resources than maize plant $\left(\mathrm{C}_{4}\right.$ plant of photosynthetic pathways) under intercropping conditions. These results are in accordance with those obtained by Idoko et al. [28] who showed that all growth and yield characters of cowpea were affected significantly by maize cultivars.

\subsubsection{Maize Planting Geometry}

Plant height, number of branches/plant, leaf area/plant, numbers of pods and seeds/plant, 100-seed weight and seed yield/fad were affected significantly by maize planting geometry in both seasons (Table 3 and Table 4). Growing two cowpea rows between maize hills by maize planting geometry $75 \mathrm{~cm} \times 140 \mathrm{~cm}$ decreased plant height of cowpea by $9.19 \%$ and $18.49 \%$ in the first season and by $10.34 \%$ or $19.41 \%$ in the second one, than those of maize planting geometry 50 $\mathrm{cm} \times 140 \mathrm{~cm}$ or $25 \mathrm{~cm} \times 140 \mathrm{~cm}$, respectively. Plant height and leaf area appeared to be the most important factor determining competition effects [31].

On the other hand, maize planting geometry $75 \mathrm{~cm} \times 140 \mathrm{~cm}$ resulted in the highest number of branches/plant, leaf area/plant, numbers of pods and seeds/plant, 100-seed weight and seed yield/fad compared with the other maize planting geometries in both seasons. Increasing distance between maize hills from 25 to $75 \mathrm{~cm}$ increased number of branches/plant, leaf area/plant, numbers of pods and seeds/plant, 100 -seed weight and seed yield/fad by $20.68 \%, 8.97 \%$, $39.50 \%, 23.92 \%, 6.65 \%$ and $13.58 \%$, respectively in the first season. Also, number of branches/plant, leaf area/plant, numbers of pods and seeds/plant, 100-seed weight and seed yield/fad were increased by $11.59 \%, 8.84 \%, 36.49 \%, 24.22 \%$, $7.82 \%$ and $14.35 \%$, respectively, by increasing distance between maize hills from 25 to $75 \mathrm{~cm}$ in the second one. These results probably due to growing two cowpea rows between maize hills through maize planting geometry $75 \mathrm{~cm} \times 140 \mathrm{~cm}$ had higher potential to harvest more light and thereby produced more branches, leaves, pods and seed per plant than those grown with the other planting geometries of maize.

It seems that when cowpea rows run north-south, maize as tall crop cannot shade easily cowpea as shorter crop and these adverse effects were increased negatively by decreasing distances between maize hills from 75 to $25 \mathrm{~cm}$. In other words, two cowpea rows between maize hills produced more leaves with greater soil cover and continued to grow and flower although the shade effects of the maize component compared with the other maize planting geometries. These results suggest that planting geometry $75 \mathrm{~cm} \times 140 \mathrm{~cm}$ formed suitable spatial arrangement of cowpea plants which reflected on decrease in inter-specific competition between the two species for climatic and edaphic environmental conditions; especially biological nitrogen fixation of the legume is dependent on the legume's ability to intercept light [32]. Accordingly, the system of intercropping is an important factor which affected the quantity on $\mathrm{N}$ fixed by legumes [33].

\subsubsection{Interaction between Maize Cultivars and Maize Planting Geometry}

Number of pods/plant and seed yield/fad were affected significantly by maize 
cultivars $\times$ maize planting geometry, meanwhile plant height, number of branches/plant, leaf area/plant, number of seeds/plant and 100-seed weight were not affected significantly by maize cultivars $\times$ maize planting geometry in both seasons (Table 3 and Table 4). The highest values of number of pods/plant and seed yield/fad were obtained by intercropping cowpea with maize cultivar TWC 352 of planting geometry $75 \mathrm{~cm} \times 140 \mathrm{~cm}$ compared with the others. These data may be due to maize cultivar TWC 352 of planting geometry $75 \mathrm{~cm} \times 140 \mathrm{~cm}$ furnished better basic growth recourses for cowpea growth and development compared with the other treatments. These data show that maize cultivars responded differently to maize planting geometry for number of pods/plant and seed yield/fad.

\subsection{Competitive Relationships}

\subsubsection{Maize Cultivars}

$\mathrm{RY}_{\text {maize }}, \mathrm{RY}_{\text {cowpea }}$, LER and LEC were affected significantly by maize cultivars in both seasons (Table 5). With respect to $\mathrm{RY}_{\text {maize, }}$, it ranged from $74 \%$ to $97 \%$ in the first season and from $78 \%$ to $98 \%$ in the second season. The highest $\mathrm{RY}_{\text {maize }}$ was obtained by intercropping cowpea with SC 30K08 compared with others in both seasons. These results may be due to plants of this cultivar had some morphological and physiological characteristics that adapted with intercropping conditions through maintaining carbon dioxide assimilation rates that reflected on better translocation of available assimilates from source to sink. On the other hand, $\mathrm{RY}_{\text {cowpea }}$ ranged from $33 \%$ to $48 \%$ in the first season and from $28 \%$ to $46 \%$ in the second season. The highest $\mathrm{RY}_{\text {cowpea }}$ was obtained by intercropping cowpea with TWC 352 compared with others in both seasons. It is important to mention that the effects of maize cultivar SC $30 \mathrm{k} 08$ on $\mathrm{RY}_{\text {cowpea }}$ were similar to those of maize cultivar TWC 310. Consequently, cowpea plants suffered from higher shading of canopy architecture of maize cultivar SC 30k08 or TWC 310 than those intercropped with maize cultivar TWC 352 which reflected negatively on their RY.

The values of LER were estimated by using data of recommended solid cultures of both crops. LER of more than 1.00 indicates yield advantage, equal to 1.00 indicates no gain or no loss and less than 1.00 indicates yield loss [34]. It can be used both for replacement and additives series of intercropping. The results obtained were strongly coincided with the definition of LER. The total LER values were greater than one in all the studied treatments (Table 5). LER ranged from 1.14 to 1.38 in the first season and from 1.14 to 1.35 in the second one. LER of 1.35 indicates that the planted area to solid cultures would need to be $35 \%$ greater than the planted area to intercrop to produce the same combined yields (i.e. $35 \%$ more land would be required as a solid crop to produce the same yield as intercropping). The advantage of the highest LER by intercropping cowpea with maize cultivar TWC 352 probably due to the canopy architecture of maize cultivar TWC 352 was more compatible with cowpea plants to continue in their growth and development compared with the others. 
Y. E. El-Ghobashy et al.

Table 5. Competitive relationships of intercropping cowpea with maize cultivars and its planting geometry in the two seasons.

\begin{tabular}{|c|c|c|c|c|c|}
\hline \multirow{2}{*}{ Maize cultivars } & \multirow{2}{*}{ Maize planting geometry } & $R Y_{\text {maize }}$ & $R Y_{\text {cowpea }}$ & LER & LEC \\
\hline & & \multicolumn{4}{|c|}{2015 season } \\
\hline \multirow{4}{*}{ S.C. $30 \mathrm{~K} 08$} & $25 \mathrm{~cm} \times 140 \mathrm{~cm}$ & 0.97 & 0.33 & 1.30 & 0.32 \\
\hline & $50 \mathrm{~cm} \times 140 \mathrm{~cm}$ & 0.90 & 0.35 & 1.25 & 0.31 \\
\hline & $75 \mathrm{~cm} \times 140 \mathrm{~cm}$ & 0.79 & 0.39 & 1.18 & 0.30 \\
\hline & Mean & 0.88 & 0.35 & 1.24 & 0.31 \\
\hline \multirow{4}{*}{ T.W.C. 310} & $25 \mathrm{~cm} \times 140 \mathrm{~cm}$ & 0.97 & 0.36 & 1.34 & 0.34 \\
\hline & $50 \mathrm{~cm} \times 140 \mathrm{~cm}$ & 0.81 & 0.40 & 1.21 & 0.32 \\
\hline & $75 \mathrm{~cm} \times 140 \mathrm{~cm}$ & 0.72 & 0.42 & 1.14 & 0.30 \\
\hline & Mean & 0.83 & 0.39 & 1.23 & 0.32 \\
\hline \multirow{4}{*}{ T.W.C. 352} & $25 \mathrm{~cm} \times 140 \mathrm{~cm}$ & 0.94 & 0.43 & 1.37 & 0.40 \\
\hline & $50 \mathrm{~cm} \times 140 \mathrm{~cm}$ & 0.81 & 0.46 & 1.27 & 0.37 \\
\hline & $75 \mathrm{~cm} \times 140 \mathrm{~cm}$ & 0.74 & 0.48 & 1.22 & 0.35 \\
\hline & Mean & 0.83 & 0.45 & 1.28 & 0.37 \\
\hline \multirow{3}{*}{$\begin{array}{l}\text { Average of maize planting } \\
\text { geometry }\end{array}$} & $25 \mathrm{~cm} \times 140 \mathrm{~cm}$ & 0.96 & 0.37 & 1.33 & 0.35 \\
\hline & $50 \mathrm{~cm} \times 140 \mathrm{~cm}$ & 0.84 & 0.40 & 1.24 & 0.33 \\
\hline & $75 \mathrm{~cm} \times 140 \mathrm{~cm}$ & 0.75 & 0.43 & 1.18 & 0.31 \\
\hline \multicolumn{2}{|c|}{ L.S.D. at 0.05 Maize cultivars } & 0.04 & 0.05 & 0.04 & 0.05 \\
\hline \multicolumn{2}{|c|}{ L.S.D. at 0.05 Maize planting geometry } & 0.03 & 0.03 & 0.02 & 0.03 \\
\hline \multicolumn{2}{|c|}{ L.S.D. at 0.05 Interaction } & 0.04 & 0.06 & 0.06 & 0.06 \\
\hline \multicolumn{2}{|c|}{ Solid culture } & 1.00 & 1.00 & 1.00 & 1.00 \\
\hline & & \multicolumn{4}{|c|}{2016 season } \\
\hline \multirow{5}{*}{ S.C. $30 \mathrm{~K} 08$} & $25 \mathrm{~cm} \times 140 \mathrm{~cm}$ & 0.98 & 0.28 & 1.26 & 0.27 \\
\hline & $50 \mathrm{~cm} \times 140 \mathrm{~cm}$ & 0.92 & 0.30 & 1.22 & 0.27 \\
\hline & $75 \mathrm{~cm} \times 140 \mathrm{~cm}$ & 0.80 & 0.34 & 1.14 & 0.27 \\
\hline & Mean & 0.90 & 0.30 & 1.20 & 0.27 \\
\hline & $25 \mathrm{~cm} \times 140 \mathrm{~cm}$ & 0.97 & 0.37 & 1.34 & 0.35 \\
\hline \multirow{2}{*}{ T.W.C. 310} & $50 \mathrm{~cm} \times 140 \mathrm{~cm}$ & 0.87 & 0.41 & 1.28 & 0.35 \\
\hline & $75 \mathrm{~cm} \times 140 \mathrm{~cm}$ & 0.78 & 0.42 & 1.20 & 0.32 \\
\hline \multirow{6}{*}{ T.W.C. 352} & Mean & 0.87 & 0.40 & 1.27 & 0.34 \\
\hline & $25 \mathrm{~cm} \times 140 \mathrm{~cm}$ & 0.94 & 0.41 & 1.35 & 0.38 \\
\hline & $50 \mathrm{~cm} \times 140 \mathrm{~cm}$ & 0.87 & 0.43 & 1.30 & 0.37 \\
\hline & $75 \mathrm{~cm} \times 140 \mathrm{~cm}$ & 0.78 & 0.46 & 1.24 & 0.35 \\
\hline & Mean & 0.86 & 0.43 & 1.29 & 0.36 \\
\hline & $25 \mathrm{~cm} \times 140 \mathrm{~cm}$ & 0.96 & 0.35 & 1.31 & 0.33 \\
\hline \multirow{2}{*}{$\begin{array}{l}\text { Average of maize planting } \\
\text { geometry }\end{array}$} & $50 \mathrm{~cm} \times 140 \mathrm{~cm}$ & 0.88 & 0.38 & 1.26 & 0.33 \\
\hline & $75 \mathrm{~cm} \times 140 \mathrm{~cm}$ & 0.78 & 0.40 & 1.19 & 0.31 \\
\hline \multicolumn{2}{|c|}{ L.S.D. at 0.05 Maize cultivars } & 0.03 & 0.06 & 0.07 & 0.06 \\
\hline \multicolumn{2}{|c|}{ L.S.D. at 0.05 Maize planting geometry } & 0.02 & 0.03 & 0.04 & 0.02 \\
\hline \multicolumn{2}{|c|}{ L.S.D. at 0.05 Interaction } & 0.05 & 0.08 & 0.08 & 0.08 \\
\hline \multicolumn{2}{|c|}{ Solid culture } & 1.00 & 1.00 & 1.00 & 1.00 \\
\hline
\end{tabular}


With respect to LEC, it was a measure of interaction concerned with the strength of relationship. LEC is used for a two-crop mixture, the minimum expected productivity co-efficient (PC) is 25 percent, that is, a yield advantage was obtained if LEC value was exceeded 0.25 . LEC was affected significantly by maize cultivars in both seasons (Table 5). LEC ranged from 0.30 to 0.40 in the first season and from 0.27 to 0.38 in the second one. The advantage of the highest LEC by intercropping cowpea with maize cultivar TWC 352 probably due to there was a decrease in interspecific competition between cowpea and maize cultivar TWC 352 for above and underground environmental conditions which reflected to higher economic yield of both species per unit area compared with the others.

\subsubsection{Maize Planting Geometry}

$\mathrm{RY}_{\text {maize, }}, \mathrm{RY}_{\text {cowpea }}$, LER and LEC were affected significantly by maize planting geometry in both seasons (Table 5). Maize planting geometry $25 \mathrm{~cm} \times 140 \mathrm{~cm}$ resulted in the highest $R Y_{\text {maize }}$ LER and LEC compared with the other maize planting geometries in both seasons. On the other hand, maize planting geometry $75 \mathrm{~cm} \times 140 \mathrm{~cm}$ resulted in the highest $\mathrm{RY}_{\text {cowpea }}$ only compared with the other maize planting geometries in both seasons. It seems that increasing distance between maize hills from 25 to $75 \mathrm{~cm}$ by growing six rows of maize in the bed (140 $\mathrm{cm}$ width) increased intraspecific competition between plants of maize for basic growth resources especially light intensity indicating low carbon dioxide assimilation rate. These results could be attributed to increase in the distance between maize hills in the same row with decreasing distance between these rows cannot increase LER and LEC which reflected negatively on the competition ability between the intercrops.

\subsubsection{Interaction between Maize Cultivars and Maize Planting Geometry} $\mathrm{RY}_{\text {maize }}, \mathrm{RY}_{\text {cowpea }}$, LER and LEC were affected significantly by maize cultivars $\times$ maize planting geometry in both seasons (Table 5). The highest $\mathrm{RY}_{\text {maize }}$ was obtained by intercropping cowpeas with maize cultivar SC 30K08 that distanced at $25 \mathrm{~cm}$ between hills compared with the others. On the other hand, the highest $\mathrm{RY}_{\text {cowpea }}$ was obtained by intercropping cowpea with maize cultivar TWC 352 that distanced at $75 \mathrm{~cm}$ between hills compared with the others. However, the highest LER and LEC were obtained by intercropping cowpea with maize cultivar TWC 352 of planting geometry $25 \mathrm{~cm} \times 140 \mathrm{~cm}$ compared with the others. It seems that two rows of cowpea plants that grown between rows of maize cultivar TWC 352 in the same bed decreased competitive ability between the intercrops for available environmental resources compared with the other treatments. Competition is a dynamic process that depends on amount of resources acquired by the competing species and their efficiency in converting resources to biomass [35]. Moreover, intercropping conditions of cereals and legumes would be valuable because the component crops can utilize different sources of $\mathrm{N}$ [36]. Accordingly, these results reveal that the advantage of the highest LER and LEC were 
Table 6. Economic evaluation of maize cultivars and its planting geometry in the two seasons.

\begin{tabular}{|c|c|c|c|c|c|}
\hline \multirow{2}{*}{ Maize cultivars } & \multirow{2}{*}{$\begin{array}{l}\text { Maize planting } \\
\text { geometry }\end{array}$} & \multicolumn{4}{|c|}{ Economic return (L.E./fad) } \\
\hline & & Maize & Cowpea & Total & Net \\
\hline \multicolumn{6}{|c|}{2015 season } \\
\hline & $25 \mathrm{~cm} \times 140 \mathrm{~cm}$ & 8986 & 6891 & 15878 & 8728 \\
\hline $\begin{array}{l}\text { Intercropping } \\
\text { culture }\end{array}$ & $50 \mathrm{~cm} \times 140 \mathrm{~cm}$ & 8400 & 7308 & 15708 & 8558 \\
\hline \multirow[t]{4}{*}{ SC 30K08 } & $75 \mathrm{~cm} \times 140 \mathrm{~cm}$ & 7326 & 8141 & 15467 & 8317 \\
\hline & Mean & 8235 & 7447 & 15682 & 8532 \\
\hline & $25 \mathrm{~cm} \times 140 \mathrm{~cm}$ & 7172 & 7658 & 14830 & 7680 \\
\hline & $50 \mathrm{~cm} \times 140 \mathrm{~cm}$ & 6023 & 8358 & 14381 & 7231 \\
\hline \multirow[t]{4}{*}{ TWC 310} & $75 \mathrm{~cm} \times 140 \mathrm{~cm}$ & 5333 & 8758 & 14091 & 6941 \\
\hline & Mean & 6177 & 8258 & 14435 & 7285 \\
\hline & $25 \mathrm{~cm} \times 140 \mathrm{~cm}$ & 7062 & 9133 & 16195 & 9045 \\
\hline & $50 \mathrm{~cm} \times 140 \mathrm{~cm}$ & 6077 & 9650 & 15727 & 8577 \\
\hline \multirow[t]{2}{*}{ TWC 352} & $75 \mathrm{~cm} \times 140 \mathrm{~cm}$ & 5522 & 10000 & 15522 & 8372 \\
\hline & Mean & 6222 & 9594 & 15816 & 8666 \\
\hline \multicolumn{6}{|c|}{ Solid culture of maize } \\
\hline \multicolumn{2}{|c|}{ SC $30 \mathrm{k} 08$} & 9243 & --- & 9243 & 2605 \\
\hline \multicolumn{2}{|c|}{ TWC 310} & 7371 & --- & 7371 & 733 \\
\hline \multicolumn{2}{|c|}{ TWC 352} & 7436 & --- & 7436 & 798 \\
\hline \multicolumn{2}{|c|}{ Mean } & 8016 & --- & 8016 & 1378 \\
\hline \multicolumn{6}{|c|}{2016 season } \\
\hline \multirow{5}{*}{$\begin{array}{l}\text { Intercropping } \\
\text { culture } \\
\text { SC } 30 \mathrm{~K} 08\end{array}$} & $25 \mathrm{~cm} \times 140 \mathrm{~cm}$ & 9295 & 4891 & 14186 & 7036 \\
\hline & $50 \mathrm{~cm} \times 140 \mathrm{~cm}$ & 8719 & 5216 & 13935 & 6785 \\
\hline & $75 \mathrm{~cm} \times 140 \mathrm{~cm}$ & 7635 & 5775 & 13410 & 6260 \\
\hline & Mean & 8547 & 5294 & 13841 & 6691 \\
\hline & $25 \mathrm{~cm} \times 140 \mathrm{~cm}$ & 7491 & 6358 & 13849 & 6699 \\
\hline \multirow{3}{*}{ TWC 310} & $50 \mathrm{~cm} \times 140 \mathrm{~cm}$ & 6674 & 6941 & 13616 & 6466 \\
\hline & $75 \mathrm{~cm} \times 140 \mathrm{~cm}$ & 5992 & 7266 & 13258 & 6108 \\
\hline & Mean & 6719 & 6855 & 13574 & 6424 \\
\hline \multirow{4}{*}{ TWC 352} & $25 \mathrm{~cm} \times 140 \mathrm{~cm}$ & 7371 & 6983 & 14354 & 7204 \\
\hline & $50 \mathrm{~cm} \times 140 \mathrm{~cm}$ & 6846 & 7416 & 14262 & 7112 \\
\hline & $75 \mathrm{~cm} \times 140 \mathrm{~cm}$ & 6180 & 7808 & 13989 & 6839 \\
\hline & Mean & 6798 & 7402 & 14200 & 7050 \\
\hline \multicolumn{6}{|c|}{ Solid culture of maize } \\
\hline & & 9470 & --- & 9470 & 2832 \\
\hline & & 7655 & --- & 7655 & 1017 \\
\hline & & 7830 & --- & 7830 & 1192 \\
\hline & & 8318 & --- & 8318 & 1680 \\
\hline
\end{tabular}

Prices of main products are that of 2018: L.E. 343 for one ardab of maize grains and L.E. 25 for one $\mathrm{kg}$ of cowpea seeds. One $\mathrm{fad}=4200 \mathrm{~m}^{2}$. One adrab $=140 \mathrm{~kg}$ of maize grains. US\$ $1=$ L.E. 18. 
achieved by growing two rows of cowpea plants between rows of maize cultivar TWC 352 in the same bed compared with the other treatments. Obviously, $\mathrm{RY}_{\text {maize }}$ contributed largely in LER and LEC than $\mathrm{RY}_{\text {cowpea }}$.

\subsection{Economic Evaluation}

The financial return of intercropping cowpea with maize as compared with solid culture of maize is shown in Table 6. Net return of intercropped cowpea with maize varied between treatments from L.E. 6941 to $9045 /$ fad as compared with solid culture of maize (L.E. 1378/fad) in the first season. Also, net return of intercropped cowpea with maize varied between treatments from L.E. 6108 to $7204 /$ fad as compared with solid culture of maize (L.E. 1680/fad) in the second one. Net return of the intercrops recorded the highest total and net returns by growing cowpea between rows of maize cultivar TWC 352 in comparison with maize solid culture in the two growing seasons. These results show that intercropping cowpea with maize cultivar TWC 352 of planting geometry $25 \mathrm{~cm} \times$ $140 \mathrm{~cm}$ is more profitable than maize solid culture for Egyptian farmers.

\section{Conclusion}

It could be concluded that growing cowpea plants with maize in the same bed to obtain high yield per unit area depend on suitable maize cultivar and its planting geometry. Regardless of maize cultivar, increasing distance between maize hills in the same row with decreasing distance between these rows cannot counterbalance the reduction in land usage and net return under intercropping conditions. Growing one row of maize cultivar SC 30K08 in both sides of bed $140 \mathrm{~cm}$ (one plant distanced at $25 \mathrm{~cm}$ ) with two rows of cowpea in middle of the bed (one plant distanced at $10 \mathrm{~cm}$ ) between maize rows recorded higher land usage and profitability than maize solid culture for Egyptian farmers.

\section{Conflicts of Interest}

The authors declare no conflicts of interest regarding the publication of this paper.

\section{References}

[1] FAO (2013) Statistical Yearbook-World Food and Agriculture. FAO, Rome.

[2] Bulletin of Statistical Cost Production and Net Return (2018) Summer and Nili Field Crops and Vegetables and Fruit, Agriculture Statistics and Economic Sector, Ministry of Egyptian Agriculture and Land Reclamation, Part (2), August 2018.

[3] Ofori, F. and Stern, W.R. (1987) Cereal-Legume Intercropping Systems. Advances in Agronomy, 41, 41-90. https://doi.org/10.1016/S0065-2113(08)60802-0

[4] Sanginga, N., Ibewiro, B., Hougnandan, P., Vantauwe, B. and Okogun, J.K. (1996) Evaluation of Symbiotic Properties and Nitrogen Econtribution of Mucuna to Maize Growth in the Derived Savannas of West Africa. Plant and Soil, 179, 119-129. https://doi.org/10.1007/BF00011649 
[5] Kumar, K. and Goh, K.M. (2000) Crop Residues and Management Practices: Effects on Soil Quality, Soil Nitrogen Dynamics, Crop Yield, and Nitrogen Recovery. Advances in Agronomy, 68, 197-319. https://doi.org/10.1016/S0065-2113(08)60846-9

[6] Palm, C.A., Giller, K.E., Mafongoya, P.L. and Swift, M.J. (2001) Management of Organic Matter in the Tropics: Translating Theory into Practice. Nutrient Cycling in Agroecosystem, 61, 63-75. https://doi.org/10.1023/A:1013318210809

[7] Futuless, K.N. and Bake, I.D. (2010) Evaluation of Yield and Yield Attributes of Some Cowpeas (Vigna unguiculata (L) Walp) Varieties in Northern Guinea Savannah. Journal of American Science, 6, 671-674.

[8] Pappa, V.A., Rees, B., Walker, R.L. and Watson, C. (2011) Intercropping of Legumes and Cereals: Effect on Yield and N Uptake in a Three Year Low Input Crop Rotation.

https://www.researchgate.net/publication/232808357_Intercropping_of_legumes_a nd_cereals_effect_on_yield_and_N_uptake_in_a_three_year_low_input_crop_rotat ion

[9] Abo-Shetaia, A.M., Abd El-Gawad, A.A., Mohamed, A.A. and Abdel-Wahab, T.I. (2002) Yield Dynamics in Four Yellow Maize (Zea mays L.) Hybrids. Arab Universities Journal of Agricultural Sciences (AJS), 10, 205-219.

[10] Ihsan, H., Khalil, I.H., Reman, H. and Iqbal, M. (2005) Genotypic Variability for Morphological Traits among Exotic Maize Hybrids. Sarhad Journal of Agriculture, 21, 599-602.

[11] Long, S.P., Ainsworth, E.A., Leakey, A.D.B., Nosberger, J. and Ort, D.R. (2006) Food for Thought: Lower-Than-Expected Crop Yield Stimulation with Rising $\mathrm{CO}_{2}$ Concentrations. Sciences, 312, 1918-1921. https://doi.org/10.1126/science.1114722

[12] Storck, L., Lopes, S.J., Filho, A.C., Martini, L.F.D. and Pisaroglo de Carvalho, M. (2007) Sample Size for Single, Double and Three-Way Hybrid Corn Ear Traits. Scientia Agricola, 64, 30-35. https://doi.org/10.1590/S0103-90162007000100005

[13] Lamlom, M.M., Abdel-Wahab, Sh.I., Abdel-Wahab, T.I. and Gendy, E.K. (2015) Chemical and Biological Influences of Some Preceded Winter Field Crops on Productivity of Intercropped Three Maize Cultivars with Soybean. Donnish Journal of Agricultural Research, 2, 55-65.

[14] Zhao, S.L., Li, F.M., Zhang, D.Y. and Duan, S.S. (1997) Crop Production Is a Population Progress. Acta Ecologica Sinica, 17, 100-104. (In Chinese with English abstract)

[15] Awan, A.R. (2013) Crop Geometry. Agrinfobank Blog Team. http://agrinfobank.blogspot.com/2013/11/crop-geometry.html

[16] Mattera, J., Romero, L.A., Cuatrín, A.L., Cornaglia, P.S. and Grimoldi, A.A. (2013) Yield Components, Light Interception and Radiation Use Efficiency of Lucerne (Medicago sativa L.) in Response to Row Spacing. European Journal of Agronomy, 45, 87-95. https://doi.org/10.1016/j.eja.2012.10.008

[17] El-Shamy, M.A., Abdel-Wahab, T.I., Abdel-Wahab, Sh.I. and Ragheb, S.B. (2015) Advantages of Intercropping Soybean with Maize under Two Maize Plant Distributions and Three Mineral Nitrogen Fertilizer Rates. Advances in BioScience and BioEngineering, 3, 30-48. https://doi.org/10.11648/j.abb.20150304.11

[18] Mead, R. and Willey, R.W. (1980) The Concept of a "Land Equivalent Ratio" and Advantages in Yields from Intercropping. Experimental Agriculture, 16, 217-228. https://doi.org/10.1017/S0014479700010978

[19] Adetiloye, P.O., Ezedinma, F.O.C. and Okigbo, B.N. (1983) A Land Equivalent 
Coefficient Concept for the Evaluation of Competitive and Productive Interactions on Simple Complex Mixtures. Ecological Modelling, 19, 27-39. https://doi.org/10.1016/0304-3800(83)90068-6

[20] Freed, R.D. (1991) MSTATC Microcomputer Statistical Program. Michigan State University, East Lansing, Michigan.

[21] Gomez, K.A. and Gomez, A.A. (1984) Statistical Procedures for Agricultural Research. 2nd Edition, John Willey and Sons, Toronto.

[22] Chang, J.H. (1974) Radiation Balance. Climatic and Agriculture. An Ecological Survey. Aldine Publishing Company, Chicago, 4-22.

[23] Paudel, M.M. (2009) Evaluation of Hybrid and OPV Maize Varieties for Grain Yield and Agronomic Attributes under Farmer's Field Conditions at Dukuchhap. Nepal Agriculture Research Journal, 9, 17-20.

[24] Shafi, M., Bakht, J., Ali, S., Khan, H., Khan, M.A. and Sharif, M. (2012) Effect of Planting Density on Phenology, Growth and Yield of Maize (Zea mays L.). Pakistan Journal of Botany, 44, 691-696.

[25] Wade, L.J., Norris, C.P. and Walsh, P.A. (1988) Effects of Suboptimal Plant Density and Non-Uniformity in Plant Spacing on Grain Yield of Rain-Grown Sunflower. Australian Journal of Experimental Agriculture, 28, 617-622. https://doi.org/10.1071/EA9880617

[26] Wade, L.J. and Douglas, A.C.L. (1990) Effect of Plant Density on Grain Yield and Yield Stability of Sorghum Hybrids Differing in Maturity. Australian Journal of $E_{X-}$ perimental Agriculture, 30, 257-264. https://doi.org/10.1071/EA9900257

[27] Valentinuz, O.R. and Tollenaar, M. (2006) Effect of Genotype, Nitrogen, Plant Density and Row Spacing on the Area-Per-Leaf Profile in Maize. Agronomy Journal, 98, 94-99. https://doi.org/10.2134/agronj2005.0111

[28] Idoko, J.A., Kalu, B.A. and Osang, P.O. (2018) Influence of Maize Varieties and Date of Planting Cowpea into Maize/Cowpea Intercropping System in Makurdi, Southern Guinea Savannah, Nigeria. International Journal of Sciences. Basic and Applied Research, 38, 98-113.

[29] Summerfield, R.J., Huxley, P.A., Dart, P.J. and Hughes, A.P. (1976) Some Effects of Environmental Stress on Seed Yield of Cowpea (Vigna unguiculata (L.) walp.) cv. Prima. Plant and Soil, 44, 527-546. https://doi.org/10.1007/BF00011373

[30] Eskandari, H. and Ghanbari, A. (2009) Intercropping of Maize (Zea mays) and Cowpea (Vigna sinensis) as Whole-Crop Forage: Effect of Different Planting Pattern on Total Dry Matter Production and Maize Forage Quality. Notulae Botanicae Horti Agrobotanici Cluj-Napoca, 37, 152-155.

[31] Qasem, J.R. and Biftu, K.N. (2010) Growth Analysis and Responses of Cowpea [Vigna sinensis (L.) Savi Ex Hassk.] and Redroot Pigweed (Amaranthus retroflexus L.), Grown in Pure and Mixed Stands, to Density and Water Stresses. The Open Horticulture Journal, 3, 21-30.

[32] Fujita, K. and Ofosu-Budu, K.G. (1996) Significance of Intercropping in Cropping Systems. In: Ito, O., Johansen, C., Adu-Gyamfi, J.J., Katayama, K., Kumar, J.V.D.K. and Rego, T.J., Eds., Dynamics of Roots and Nitrogen in Cropping Systems of The Semi-Arid Tropics, Japan International Research Center for Agricultural Sciences, Ohwashi, Int. Agric. Series No. 3, 19-40.

[33] Rerkasem, B., Rerkasem, K., Peoples, M.B., Herrigde, B.F. and Bergersen, F.J. (1998) Measurement of $\mathrm{N}_{2}$ Fixation in Maize Rice Bean Intercrops. Plant and Soil, 108, 125-135. https://doi.org/10.1007/BF02370107 
[34] Vandermeer, J.H. (1989) The Ecology of Intercropping. Cambridge Univ. Press, New York. https://doi.org/10.1017/CBO9780511623523

[35] Kropff, M.J. and Lotz, L.A.P. (1992) Systems Approach to Quantify Crop-Weed Interactions and Their Application to Weed Management. Agricultural Systems, 40, 265-282. https://doi.org/10.1016/0308-521X(92)90024-I

[36] Chu, G.X., Shen, Q.R. and Cao, J.L. (2004) Nitrogen Fixation and N Transfer from Peanut to Rice Cultivated in Aerobic Soil in Intercropping System and Its Effect on Soil N-Fertility. Plant Soil, 263, 17-27.

https://doi.org/10.1023/B:PLSO.0000047722.49160.9e 